\title{
Improving students' reading comprehension by using mind mapping technique through miMind Applicationas android based mobile learning at the first grade of SMAN 1 Sumberejoin academic year 2020/2021
}

\author{
Dhea Novitasari ${ }^{1}$, Khairun Nisa ${ }^{2}$ \\ English Education Study Program, University of Lampung \\ dheanovitasari79@gmail.com ${ }^{1}$
}

\begin{abstract}
The objectives of this research are: (1) to find out the significant difference of using mind mapping through miMindapplication in improving students' reading comprehension of narrative text; and (2) to know the students' responses toward miMindapplication as android based mobile learning. This is a quantitative study which had intact group pre-test and post-test design. Therefore, the effectiveness of this study can be seen through the significant difference before and after the implementation of mind mapping technique through miMindapplication as revealed on the students' scores. This research was conducted at the first year of SMAN 1 Sumberejo in academic year 2020/2021. The sample of this research was X MIPA 1 consisted of 36 students which was selected by using cluster random sampling. The research data were collected by using reading test and questionnaire.
\end{abstract}

The results show that students' mean scores in the pre-test was 61.18 and post-test was 76.81 . It can be seen that the students' mean score of post-test increased about 15.63 point after being taught by using mind mapping technique through miMindapplication. Then, the results were computately analyzed using Paired Samples T-Test through SPSS 20 Program, which showed that t-value (6.780) was higher than t-table (2.0301) at level of significance 0.05. Based on this result, $\mathrm{H}_{0}$ was rejected, while $\mathrm{H}_{1}$ was accepted. In other words, there is significant difference between the students' reading comprehension in narrative text before and after the implementation of mind mapping technique through miMind application in SMAN 1 Sumberejo. It was also supported by the students' responses in questionnaire. From the result, there were $89 \%$ students gave positive response and $11 \%$ gave negative response toward mind mapping through miMindapplication. It can be concluded that mind mapping technique through miMindapplication is effective to improve students' reading comprehension of narrative text.

Keywords: Reading Comprehension, Mind Mapping Technique, miMindApplication, Android, Mobile Learning

\section{INTRODUCTION}

Reading is the most crucial language skill because it is the base of knowledge (Birch, 2014) in Khalid et al.(2018:2). This skill has a vital meaning on humans; that is why it is the crucial reason for learning and proficiency. Reading is also a distinctive procedure which rounds through eyes, speech, and mind (Alshehri, 2014) in Khalid et al.(2018:2). It indicates that reading is an active process which involved many aspects. Moreover, the act of reading cannot be separated from comprehension (Indrayani, 2014). The students cannot get their reading achievement within comprehending what they read. In comprehending a text, students should be taught and monitored by teacher who well understood the way to teach reading comprehension 
properly. The main purpose of teaching the reading skill is to train the students so that they could attain ideas and information to comprehend a text.

According to Kemdikbud, as the ministry of the Government of Indonesia that responsible in the field of early childhood education, primary education, secondary education, public education, and management culture(Hidayatsrf, 2020), on High School Syllabus of Curriculum 2013 verse 2018 revision, the first grade of senior high school students are expected to learn some types of text, such as introduction, extended, showing care, intention, descriptive, announcement, recount, and narrative. Narrative is a common text which is used in teaching and learning activities and national examination (Septiyani, 2017). Furthermore, narrative text is a text which tells a story using a series of events (NSW Department of Education and Communities, 2011: 3) in Septiyani(2017). In line with the purpose that is to entertain the readers, it can be assumed that narrative text can be interesting and easy to study.

However, many students find difficulties that often appear in comprehending a reading text, in this case is narrative text. Due to the fact, students have difficulty understanding stories that they read (Garcia et al., 2014). It indicates that the students can read aloud the text, but they do not understand and remember what the text talks about. Most of students read for many times to get some information they are looking for. In contrast, reading is a long process (Septiyani, 2017). While the time is limited, but they fail in getting the information, they prefer to answer quickly rather than comprehend the text deeply. Consequently, they will get unsatisfying achievement in reading comprehension. Furthermore, it is not about the students' problem, but also the teacher's. Aside from students, teachers may be the most reliable source of information concerning boredom in students during class instruction (Daschman et al., 2013). When teachers cannot package the material effectively, students who feel tired after full day class in high school will also get less interesting to learn something, especially to comprehend a text. Therefore, teachers should have teaching and learning techniques that can help students improve their achievement (Kusmaningrum, 2016). In addition, the usage of media is also important to support teaching and learning technique in getting better understanding. Considering that facts, it is needed for teacher to find an effective technique in teaching reading comprehension, so that the students will get the proper ideas and needed information from a text that they read. For this reason, mind mapping is one of the best answers that can help students in improving their reading comprehension of narrative text.

Mind mapping is an effective technique for students to get better understanding and remember the important lessons. Due to the fact, mind map enhanced and enriched through color, pictures, code, and dimension to add interest, beauty, and individuality(Liztyanputri, 2016). This is important to help the students in learning creatively and memorizing the recall information specifically. Some previous researchers used mind mapping technique to be applied in learning process. The first research was done by Patria(2015), entitled Increasing Students' Reading Comprehension through Mind Mapping Technique from Narrative Text. The result of mind mapping was effective to increase the students' reading comprehension of narrative text. The second research was done by Rizqiya(2013), entitled The Use of Mind Mapping in Teaching Reading Comprehension. The result of mind mapping was effective to be an alternative technique in teaching reading comprehension. The result of the students' tasks indicated that the students' reading comprehension increase after being taught by using mind mapping technique. 
However, these previous studies have not given in depth information to which of media of mind mapping in reading comprehension itself. It is most useful.

Referring the afore mentioned studies, it is reasonable to assume that students will probably avail themselves of mind mapping in terms of generating an organizing ideas for their reading comprehension of narrative text. Yet, it was also the researcher's assumption that, if it was manual mind mapping, it would be less effective since they would organize the ideas of the text by creating nodes and lines on their book by obvious stationary such as book, pen, ruler, even color tools. In addition, creating a mind map is a very personal process. It means that mind map between one student and another student will be different. It will lead the difficulty for students to start organize their mind map if there is no significant map reference to do that. Furthermore, the development of science and technology encourages various reform efforts in learning process (Wicahyani et al., 2018). Given the findings and deductions regarding the usage of media above, the researchers assumed that mind mapping through android application as digital media can be more effective than manual media.

M-learning (Mobile learning) is a kind of learning model allowing learners to obtain learning materials anytime and anywhere using mobile communication, mobile devices, and the internet(Lan and Sie, 2010). It means that mobile learning is closely related with nowadays learners' situation that lives in technology development era. Particularly, with the mobile technologies, learners and instructors should make different activities which are more motivational and more interesting from traditional activity (Ozdaml and Cavus, 2011). So, by using android application as the mobile device of digital media, students can create and bring their mind map just by using their smartphone that can be used anytime and anywhere. The students do not need obvious stationary and a long time to think about their map shape and how to connect each node properly because the device can be used simpler than it. Just organize the ideas and choose some types, color, and background, then the proper mind map can be gotten. In consideration of all this, the researchers conducted a study on the effectiveness of mind mapping technique through android application.

In relation to mobile learning of mind mapping, miMind is might be applicable since they may use an easy device to create their mind map. Many researchers have been conducted dealing with miMind in the scope of mind mapping activities. For example, Hermawati et al., (2019)who stated that miMindapplication gave significant effect (positive) towards students' achievement that is 33 as the highest percentage. They said this application is very good to be implemented at school, especially in English course, because the learning process ran more effective, efficient and innovative, saving time, and students also can learn everywhere. It is possible for students to keep learning even though they do not do face-to-face class. Another research came fromGolovatina and Golovatina-Mora(n.d.:2), stated that miMindis an appropriate application that can help the students to develop a mind map. In line with this, Castillo and Gullen(2020) who stated that miMind was an ideal digital application for retrieving and organizing information in Harmonic Mind Maps.

However, all the previous studies purely only implemented the concept of manual mind mapping in reading comprehension of narrative text, or students only use miMind application for their digital learning achievement. By modifying this mind mapping, that is the concept of 
miMind, it will provide the students an ideal and appropriate digital application for doing mind map of narrative text. Moreover, hopefully it will facilitate the students' mind mapping activity, so that they can comprehend their reading of narrative text properly. miMind mobile application was used for digital learning which is considered more effective and enjoyable than the manual verse, and mind mapping was used as simple note and graphic organizer of the ideas of narrative text that is comprehended by students. When the students can enjoy their learning, they can read and understand the text easier. Therefore, a success in comprehending a text will be easily achieved. It is also related to their perception. Furthermore, the students's responses related to the use of mind mapping technique which is modified by android mobile learning, whether it can motivate their learning or not, can also be seen from the result of questionnaire as one the instruments of this research.

Based on the explanation above, the researcher was highly motivated to conduct a research entitled“'Improving Students' Reading Comprehension by Using Mind Mapping Technique through miMindApplication as Android based Mobile Learning at The First Grade of SMA N 1 Sumberejo in Academic Year 2020/2021”.

\section{METHODS}

This research was a quantitative study since it was focused on the product (result of the test) not the process of teaching learning. This present study had one group pre-test post-test design. In this research, the researcher used regression study. Regression was used to predict the effect of dependent variable toward independent variable. The researcher selected the class by using cluster random sampling. The learners received the questionnaire. There were three treatments, the students were tested before and after the treatment. After the treatment, the students were given a set of questionnaire in order to know the students' response toward the technique being implemented. The research design can be represented as follow:

\section{$\mathbf{T}_{1} \mathbf{X} \quad \mathbf{T}_{2}$}

Notes:

$\mathrm{T}_{1}:$ Pre-test

$\mathrm{T}_{2}:$ Post-test

$\mathrm{X}$ : Treatment

(Setiyadi, 2018)

\section{Participants}

This research was conducted at the first year of SMAN 1 Sumberejo in academic year 2020/2021. The sample of this research was X MIPA 1 consisted of 36 students which was selected by using cluster random sampling.

\section{Instruments}

The research data were collected by using reading test and questionnaire.

\section{Data analysis}

The data of this study was computately analyzed using Paired Samples T-Test through SPSS 20 Program.Then, to examine the result of questionnaire in analyzing the learners' response toward 
mind mapping technique through miMind application, the researcher analyzed its quantitative data and description analysis was used, since the researcher uses his own idea including his own interpretation toward the data(Setiyadi, 2018). In addition to test measurement, the researcher also applied the honesty test to the students when they took the test by using Auto Proctor Program on a Google Form containing tests for students to work on to minimize the form of students cheating referring to the fact that currently online learning are implemented due to the COVID-19 Pandemic.

\section{RESULTSAND DISCUSSIONS Result of Reading Test}

The pretest and posttest results of 36 students in experimental class were analyzed. The total of the pre-test score before the treatment of teaching reading comprehension through mind mapping technique by using miMind application was implemented was 2202.48 , mean score was 61.18 , the highest score was 95 and the lowest score was 15 . The median of pretest was 66.25 , the mode was 85 , and standard deviation of the pretest result was 25.44.

The total of post-test score after the treatment of teaching reading through mind mapping technique was implemented was 2765.16, mean score was 76.81, the highest score was 95 and the lowest score was 27.5. The median was 87.5, the mode was 90, and standard deviation of the posttest result was 21.23. The students' scores in post-test were higher than their scores in the pre-test. Therefore, the treatment of teaching reading through mind mapping technique gave a good contribution to attainment of reading comprehension.

\section{The Improvement of the Students' Reading Comprehension}

The scores were divided into 3 groups: increased, stable, and decreased, to further investigation in what way the implementation of mind mapping technique by using miMind application had an effect on the students' reading comprehension. Based on the overall data gained in experimental class, it was found that from the total of 36 students, there were 34 (94.44\%) students whose the score increased on posttest. Then, there were $2(5.56 \%)$ other students whose the score were stable. Last, there were no students who have score decreased.

\section{Honesty Test}

The honesty test of all the students was $100 \%$. It indicates that the students did the test by avoiding such a cheating that can be detected through Auto Proctor Program when they took their tests. The researcher gave the instruction before the students took the test so that the students knew what to do and what not to do. It was also accordance to the instruction of the Auto Proctor Program itself that the teacher should tell the students about the further instruction and information if the students take the test by using the program. After all the students have submitted their tests, the results will be shown in add-ons on Google Form.

\section{Hypothesis Testing}

In testing the hypothesis, the result was analyzed by using Paired Samples T-Test through SPSS 20 Program thatwas depicted in Table 1 as follows. 
Table 1. T-test Result

Paired Samples Test

\begin{tabular}{|c|c|c|c|c|c|c|c|c|}
\hline & \multicolumn{5}{|c|}{ Paired Differences } & \multirow[b]{3}{*}{$\mathrm{T}$} & \multirow[b]{3}{*}{ Df } & \multirow{3}{*}{$\begin{array}{l}\text { Sig. } \\
(2- \\
\text { tailed })\end{array}$} \\
\hline & \multirow[b]{2}{*}{ Mean } & \multirow{2}{*}{$\begin{array}{c}\text { Std. } \\
\text { Deviation }\end{array}$} & \multirow{2}{*}{$\begin{array}{l}\text { Std. } \\
\text { Error } \\
\text { Mean }\end{array}$} & \multicolumn{2}{|c|}{$\begin{array}{l}\text { 95\% Confidence } \\
\text { Interval of the } \\
\text { Difference }\end{array}$} & & & \\
\hline & & & & Lower & Upper & & & \\
\hline $\begin{array}{ll}\text { Pair } & \text { Posttest }- \\
1 & \text { Pretest }\end{array}$ & 15.6250 & 13.8277 & 2.3046 & 20.3036 & 10.9464 & 6.780 & 35 & .000 \\
\hline
\end{tabular}

From Table 1, it presented that the t-test of this research was 6.780 and the t-table was 2.0301 based on the $\mathrm{df}$ (degrees of freedom), which was 35, at a level significant of 0.05 . It can be seen from the calculation of reading test result between pretest and posttest, $\mathrm{H}_{0}$ was rejected, while $\mathrm{H}_{1}$ was accepted because t-value was more than t-table (6.780> 2.0301). Therefore, it can be concluded that therewas significant difference between the result of pretest and the result of posttest. In other words, there was significant difference between the students' reading comprehension in narrative text before and after the implementation of mind mapping technique through miMind application.

\section{Result of Questionnaire}

The questionnaire consists of 45 questions that indicated the students' interest toward mind mapping technique through miMind application and the effects of the implementation of mind mapping technique through miMind application to their knowledge improvement and reading skills, especially in narrative text. Each item has 5 numerical value:sangat setuju ( $S S$ ) has 5 points, setuju (S) has 4 points, kurang setuju (KS) has 3 points, tidak setuju (TS) has 2 points, and sangat tidak setuju (STS) has 1 point.The distribution frequency of the students' questionnaire can be seen through the Table 2 below.

Table 2. Distribution Frequency of the Students' Questionnaire

\begin{tabular}{llll}
\hline No. & Interval & Frequency & $\%$ \\
\hline 1 & $149-159$ & 1 & $2.78 \%$ \\
2 & $160-170$ & 0 & $0 \%$ \\
3 & $171-181$ & 3 & $8.33 \%$ \\
4 & $182-192$ & 10 & $27.78 \%$ \\
5 & $193-203$ & 5 & $13.88 \%$ \\
6 & $204-214$ & 6 & $16.67 \%$ \\
7 & $215-225$ & 11 & $30.56 \%$ \\
\hline & Total & 208 & $100 \%$ \\
\hline
\end{tabular}

From the table above, it can be concluded that $89 \%$ of all students give positive response toward mind mapping technique.

\section{Disscussion}

Due to this research was done in one class only: experimental class, then, all the data which described is the data of the stated experimental class only. This research uses design by Setiyadi, 2018, namely one group pre-test and post-test design. The pretest mean score was 61.18. Meanwhile, after given 3 treatments by using mind mapping technique through 
miMindapplication, the posttest mean score was 76.81. The increase of the mean score in experimental class can be based on the quality of learning process that was getting better in few of the fact that the students ability in comprehending narrative text developed well. In addition, the students might also enjoy the learning process.

After finding the mean score in both of tests: pretest and posttest, the researcher made sure that the data were distributed normally. The value 0.200 for both of pretest and posttest was found through normality test. The value was higher than 0.05 , which means the data were distributed normally. In other words, there was balance distribution between the students who got low, middle, and high score.

After that, the researcher calculated the data into t-test formula by using SPSS 20 Program. From the calculation, the result of t-test was 6.780. This result needed to be compared to t-table value. Based on a level significance of 0.05 , the t-table value obtained was 2.0301 . Then, the researcher compared t-test and t-table value and found that the t-test was higher than t-table value, which were $6.780>2.0301$. Based on this result, $\mathrm{H}_{0}$ or null hypothesis was rejected, while $\mathrm{H}_{1}$ or alternative hypothesis was accepted. In other words, there is significant difference between the students' reading comprehension in narrative text before and after the implementation of mind mapping technique through miMind application in SMA $\mathrm{N} 1$ Sumberejo, Tanggamus, Lampung. The similar topic was also carried out by some previous researchers about mind mapping technique to be applied in learning process. The first research was done by Rachma Patria(2015) entitled Increasing Students' Reading Comprehension through Mind Mapping Technique from Narrative Text. The result of mind mapping was effective to increase the students' reading comprehension of narrative text which showed that $7.050>2.045$. The second research was done byRizqiya(2013), entitled The Use of Mind Mapping in Teaching Reading Comprehension. The result of mind mapping was effective to be an alternative technique in teaching reading comprehension. Due to the researcher modified the technique by using mobile learning, that is miMind application, then, several studies were referred to in this study. As a research by Hermawati et al.(2019) who stated that miMindapplication gave significant effect (positive) towards students' achievement that is 33 as the highest percentage. Another research came fromGolovatina and Golovatina-Mora(n.d.:2) stated that miMindis an appropriate application that can help the students to develop a mind map. In line with this, Castillo and Gullen(2020)who stated that miMind was an ideal digital application for retrieving and organizing information in Harmonic Mind Maps.

In addition to the hypothesis testing which showed that there was significant difference between the students' reading comprehension in narrative text before and after the implementation of mind mapping technique through miMind application in SMA $N 1$ Sumberejo, the implementation of present study showed that using mind mapping technique through miMind application had positive responses in the experimental class. This was based on the questionnaire result showing that $55.6 \%$ of students strongly agreed that mobile learning generated student's interest in reading comprehension of narrative text, because it presents learning material attractively by equipping with pictures, animation, and learning videos. Furthermore, $52.8 \%$ of students agreed that mobile learning can be used anywhere and anytime which can be operated without the help of the teacher directly. This is accordance with the current learning conditions-online learning during Covid 19 Pandemic, especially at SMA N 1 
Sumberejo which is implementing online learning with a duration of learning time of $1 \times 65$ minutes each week. Moreover, 58.3\% of students strongly agreed that mobile learning helps overcome learning difficulties, because it can help improve the students' memory of the subject matter. As Tee et al.(2014)says that mind maps help students remember information, as they hold it in a format that the mind finds easy to recall and quick to review. Furthermore, the advancement of technology leads the technique to use in concept of android based mobile learning. One of them is about application usage, in this case is mind mapping application, that is miMind application. By using mind mapping technique through miMind application as the device of mobile learning, the learning process can be more flexible since it can be done anytime, anywhere and in any condition(Martono and Nurhayati, 2014). It can also help students with staying focused, goal settings, color-coding, assignments, qualitative analysis, budgeting. It is found that students have better understanding to a text they read, in this case is narrative text. By having a better understanding, there is an improvement in their confidence in answering any questions either from the teacher or questions of an exam or test. Moreover, mind mapping through miMind application is a modified technique that is very good to be implemented at school, especially in English course, because the learning process ran more effective, efficient and innovative, saving time, and students also can learn everywhere (Hermawati et al., 2019). In addition, they said that it is possible for students to keep learning even though they do not do face-to-face class.

\section{CONCLUSIONS AND SUGGESTIONS \\ Conclusions}

Based on the result of analyzing the data, there was significant difference between the students' reading comprehension in narrative text before and after the implementation of mind mapping technique through miMind application at the first grade of SMA N 1 Sumberejo in academic year 2020/2021. It means there is an effectiveness of using mind mapping technique through miMind application on students' reading narrative text. It was due to the fact that the implementation of mind mapping technique through miMind application showed positive responses in experimental class by the increase of mean score and the number of students who received higher score. The fact showed that almost all students of the class received higher scores after being given the treatment. It means that the number of the students who received stabled scores after the treatment were less than the number of the students who received higher scores. Another fact showed that there were no students who received lower score after being given the treatment.

In addition to the significant difference between the students' reading comprehension in narrative text before and after the implementation of mind mapping technique through miMind application at the first grade of SMA N 1 Sumberejo in academic year 2020/2021, the questionnaire result showed that reading comprehension of narrative text by using mind mapping technique through miMind application gave positive impact for the students' learning. On the condition that the students have a deeper understanding about the concept of mind mapping technique through miMind application, so that the technique which is modified by android based mobile learning can be implemented effectively on students' reading comprehension of narrative text. 
From the effectiveness, it indicates that mind mapping as a visual diagram which is modified by the usage of miMindapplication as android based mobile learning has sucessfully motivated the students to read narrative text in a joyful way. The students who get less interesting to learn something because they feel tired after full day class can minimize their boredom in comprehending a text by using miMindapplication on their gadget. They can create an interesting map by using some colors and pictures which can be digitally organized anytime and anywhere. For this reason, mind mapping through miMindapplication is one of the best answers that can help students in improving their reading comprehension of narrative text. Furthermore, considering to the readers in all grades like a joyful process in comprehending a text, therefore, mind mapping technique is not only limited to senior high school students, but it is also flexible to be implemented in all grades, such as elementary school students, junior high school students, even for college students, and in all subjects.

\section{Suggestions}

Based on the conclusion of the study, the suggestions are addressed to students, English teachers, the other researchers, and school.For the students, they should be aware of the new learning technique that they can use to support their learning process, because one technique may work better than the others. In addition, every student definitely has one learning technique that suit them best.While, the teachers should be careful in determining the term of implementing a technique to make sure that the students understand any of material explained by the teacher.Then, the other researchers can use this study as a relevant study related to the implementation of mind mapping technique through miMind application as android based mobile learning to improve students' reading comprehension of narrative text.Furthermore, the school should better support the teacher in implementing a technique by giving proper time, place, and facilities for the success of knowledge transform from the teachers to the students.

\section{REFERENCES}

Castillo, P. N., \& Gullen, D. E. F. (2020). Digital application strategies in the understanding of scientific texts.

Daschman, E. C., Goetz, T., \& Stupnisky, R. H. (2013). Exploring the antecedents to boredom: Do teachers know why students are bored? Teaching and Teacher Education, 24.

Garcia, Y. P., Ramayan, A. J. R., Sepe, A. P., Silor, A. C., Castillon, B. M., \& Rosel, M. T. P. (2014). Difficulties in reading comprehension and metacognitive strategies for technology livelihood education students. Global Summit on Education GSE, 250.

Golovatina, V., \& Golovatina-Mora, P. (n.d.). Mobile application in the Russian Language Class: Revisions and reflections. Innovation in Language Learning, 2.

Hermawati, K. L., Sugihartini, N., \& Putra, G. S. S. (2019). Pengaruh metode mind mapping menggunakan Aplikasi mi-Mind serta Edmodo terhadap prestasi belajar komputer dan jaringan dasar. International Journal of Natural Sciences and Engineering, 3. 35.

Hidayatsrf. (2020). Kementerian Pendidikan dan Kebudayaan Republik Indonesia. In Wikipedia.

https://id.m.wikipedia.org/wiki/Kementerian_Pendidikan_dan_Kebudayaan_Republik_Ind onesia

Indrayani, S. A. (2014). The effectiveness of using mind mapping in improving students' reading comprehension of narrative text.Unpublished Undergraduate Thesis: Lampung University.

Khalid, M., Mehmood Sajid, \& Fraidan, A. Al. (2018). Effectiveness of reading aloud strategies for inferential reading comprehemsion skills and text difficulties of saudi students at university level. International Journal of Innovative Technology and Exploring Engineering, 2. 
Kusmaningrum, M. (2016). Using mind-mapping to improve reading comprehension and writing achievements of the 4th semester students of STAIN Curup. Journal English of Literacy Education, 3, 188.

Lan, Y.-F., \& Sie, Y.-S. (2010). Using RSS to support mobile learning based on media richness theory. Computers \& Education, 723.

Liztyanputri, R. A. (2016). The effect of using mind mapping to improve the students reading compehension in narrative text of the eleventh grade students at SMK PGRI 4 Kediri in academic year 2015/2016. Universitas Nusantara PGRI, 4-6.

Martono, K. T., \& Nurhayati, O. D. (2014). Implementation of android based mobile learning application as a flexible learning media. International Journal of Computer Science Issues, $11(3), 174$

Ozdaml, F., \& Cavus, N. (2011). Basic elements and characteristics of mobile learning. Procedia-Social and Behavioral Science, 938.

Patria, R. (2015). Increasing students' reading comprehension through mind mapping technique from narrative text. Unpublished Undergraduate Thesis: Lampung University.

Patria, Rachma, Sukirlan, M., \& Simanjuntak, E. G. (2015). Increasing students' reading comprehension through mind mapping technique from narrative text. http://digilib.unila.ac.id/6952

Rizqiya, R. S. (2013). The use of mind mapping in teaching reading comprehension. ELTIN Journal, 32 and 43.

Septiyani, A. D. (2017). The effectiveness of mind mapping technique in teaching reading comprehension of narrative text at the second grade students' of SMA Al-Hikmah Mayong in the academic year of 2017/2018. Jurnal Edulingua, 4, 82.

Setiyadi, A. B. (2018). Metode penelitian untuk pengajaran bahasa asing: Pendekatan kuantitatif dan kualitatif (2nd ed.). Graha Ilmu.

Tee, T. K., Azman, M. N. A., Mohamed, S., Muhammad, Yunos, J. M., Yee, M. H., \& Othman, W. (2014). Buzan mind mapping: An efficient technique for note-taking. Internationaal Journal of Psychological and Behavioral Sciences, 8, 30.

Wicahyani, S., Handayani, O. W. K., \& Hartono, M. (2018). Design android application my mind mapping (M3) physical education, sport, \& health subject curriculum 2013 for teachers guidance Xth grade vocational high school. Journal of Physyical Education and Sport,74. 